\title{
UPAYA MENINGKATKAN KEMAMPUAN SISWA DALAM MENYEDERHANAKAN DAN MENGURUTKAN PECAHAN DENGAN MENGGUNAKAN MEDIA PAPAN PLANEL (PTK di Kelas VI-B SDN Karsamenak Kota Tasikmalaya)
}

Oleh :

Tatik Maryati

\begin{abstract}
ABSTRAK
Berhasil tidaknya pembelajaran sangat tergantung kepada kemampuan guru dalam mengelola pembelajaran.Guru merupakan ujung tombak paling depan dalam mewujudkan keberhasilan penyelenggaraan pembelajaran dan pendidikan pada tingkat satuan pendidikan.Salah satunya adalah kemampuan guru dalam menggunakan media pembelajaran Papan Planel.Kompetensi siswa yang ditingkatkan melalui Penelitian Tindakan Kelas ini adalah Menyederhanakan dan Mengurutkan Pecahan dengan menggunakan media Papan Planel sehingga diharapkan adanya peningkatan pencapaian target dalam Ketuntasan Minimal.Rumusan masalah pokok adalah"Meningkatkan Kemampuan Siswa dalam Menyederhanakan dan Mengurutkan Pecahan dengan Menggunakan Media Papan Planel".Tujuan penelitian ini adalah untuk Penelitian Tindakan Kelas(PTK) dengan melakukan 2 (dua) siklus tindakan,yang pada setiap siklus dilakukan melalui tahapan tahapan observasi,wawancara,dan tes untuk pengumpulan data.

Hasil penelitian menunjukan bahwa 1) proses pembelajaran Matematika tentang Menyederhanakan dan Mengurutkan Pecahan dengan Media Papan Flanel di Kelas VI B SDN Karsamenak menunjukkan peningkatan dari siklus ke siklus .Hal ini terlihat dengan peningkatan rata-rata skor dari 2,15 atau $53,75 \%$ pada para tindakan menjadi 2,78 atau $69,5 \%$ pada siklus I ,Dan semakin meningkat pada siklus II yaitu 3,3 atau 94,1 \%. 2) aktivitas siswa pada pembelajaran Matematika tentang Menyederhanakan dan Mengurutkan Pecahan dengan Media Papan Flanel di Kelas VI B.SDN.Karsamenak menunjukkan peningkatan dari siklus ke siklus.Hal ini terlihat dengan peningkatan rata-rata skor 1,9 atau $38 \%$ pada Para Tindakan menjadi 2,9 atau $58 \%$ pada siklus 1,kemudian 4,4 atau $88 \%$, 3) hasil belajar siswa pada pembelajaran Matematika tentang Menyederhanakan dan Mengurutkan Pecahan dengan Media Papan Flanel di Kelas VI B SDN.Karsamenak,menunjukkan peningkatan dari siklus ke siklus.Hal ini terlihat dengan peningkatan rata-rata skor dari 36,28 atau 46,51\% pada Para Tindakan menjadi 55,16 atau 70,07 \% pada Siklus 1.Kemudian semakin meningkat pada Siklus II yaitu 76,8 atau $98,46 \%$.
\end{abstract}

Kata kunci: Hasil Belajar Siswa, Media Pembelajaran Papan Planel

\footnotetext{
${ }^{1}$ Penulis adalah Guru Kelas SD Negeri Kersamenak Tasikmalaya
} 


\section{A. Pendahuluan}

Sistem Pendidikan Nasional tertuang dalam Undang-Undang Dasar Negara Republik Indonesia Nomor 20 Tahun 2003.Undang-undang tersebut merupakan kebijakan pemerintah dalam bidang pendidikan, yang menyiratkan makna dan tujuan untuk meningkatkan kualitas pendidikan di Indonesia. Kualitas pendidikan merupakan hal yang harus diperhatikan seiring dengan kemajuan teknologi dan informasi yang semakin cepat saat ini. Menurut Tim MKPBM (2001:28) "Matematika sebagai ratu atau ibunya ilmu dimaksudkan bahwa matematika adalah sumber dari ilmu yang lain". Penguasaan ilmu dasar seperti matematika dapat mempermudah dalam upaya peningkatan mutu pendidikan yang pada akhirnya tercipta suatu sistem pendidikan yang memadai.Matematika merupakan ilmu universal yang mendasari perkembangan teknologi modern, mempunyai peran penting dalam berbagai disiplin dan memajukan daya pikir manusia.Perkembangan pesat di bidang teknologi informasi dan komunikasi dewasa ini dilandasi oleh perkembangan matematika di bidang teori bilangan, aljabar, analisis, teori peluang dan matematika diskrit. Untuk menguasai dan mencipta teknologi di masa depan diperlukan penguasaan matematika yang kuat sejak dini.

Mata pelajaran Matematika perlu diberikan kepada semua peserta didik mulai dari sekolah dasar untuk membekali peserta didik dengan kemampuan berpikir logis, analitis, sistematis, kritis, dan kreatif, serta kemampuan bekerjasama. Kompetensi tersebut diperlukan agar peserta didik dapat memiliki kemampuan memperoleh, mengelola, dan memanfaatkan informasi untuk bertahan hidup pada keadaan yang selalu berubah, tidak pasti, dan kompetitif. Standar kompetensi dan kompetensi dasar matematika dalam dokumen ini disusun sebagai landasan pembelajaran untuk mengembangkan kemampuan tersebut di atas. Selain itu dimaksudkan pula untuk mengembangkan kemampuan menggunakan matematika dalam pemecahan masalah dan mengkomunikasikan ide atau gagasan dengan menggunakan simbol, tabel, diagram, dan media lain.

Pendekatan pemecahan masalah merupakan fokus dalam pembelajaran matematika yang mencakup masalah tertutup dengan solusi tunggal, masalah terbuka dengan solusi tidak tunggal, dan masalah dengan berbagai cara penyelesaian. Untuk meningkatkan kemampuan memecahkan masalah perlu dikembangkan keterampilan memahami masalah, membuat model matematika, menyelesaikan masalah, dan menafsirkan solusinya.

Dalam setiap kesempatan, pembelajaran matematika hendaknya dimulai dengan pengenalan masalah yang sesuai dengan situasi (contextual problem). Dengan mengajukan masalah kontekstual, peserta didik secara bertahap dibimbing untuk menguasai konsep matematika. Untuk meningkatkan keefektifan pembelajaran, sekolah diharapkan menggunakan teknologi informasi dan komunikasi seperti komputer, alat peraga, atau media lainnya. Berdasarkan Kurikulum Tingkat Satuan Pendidikan (KTSP) yaitu agar peserta didik memiliki kemampuan sebagai berikut (Widaningsih, Dedeh, 2007:11) :

1. Memahami konsep matematika, menjelaskan keterkaitan antar konsep dan mengaplikasikan 
konsep atau algoritma, secara luwes, akurat, efisien, dan tepat, dalam pemecahan masalah.

2. Menggunakan penalaran pada pola dan sifat, melakukan manipulasi matematika dalam membuat generalisasi, menyusun bukti, atau menjelaskan gagasan dan pernyataan matematik.

3. Memecahkan masalah yang meliputi kemampuan memahami masalah, merancang model matematika, menyelesaikan model dan menafsirkan solusi yang diperoleh.

4. Mengkomunikasikan gagasan dengan simbol, tabel, diagram, atau media lain untuk memperjelas keadaan atau masalah.

5. Memiliki sikap menghargai kegunaan matematika dalam kehidupan, yaitu memiliki rasa ingin tahu, perhatian, dan minat dalam mempelajari matematika, serta sikap ulet dan percaya diri dalam pemecahan masalah..

Mata pelajaran Matematika pada satuan pendidikan SD/MI meliputi aspek-aspek sebagai berikut.

1. Bilangan

2. Geometri dan pengukuran

3. Pengolahan data.

Saat ini siswa kelas VI B SDN.Karsamenak ,UPT Wilayah Selatan Kota Tasikmalaya,berjumlah 25 siswa dengan perincian 13 orang lakilaki dan 12orang siswa perempuan.Berdasarkan pengamatan selama pembelajaran dan data hasil tes awal pada pelajaran matematika dengan Kompetensi Dasar "Menyederhanakan dan Mengurutkan Pecahan"pada semester genap,kemampuan siswa kelas VI B sangat rendah.Dari 25 orang siswa hanya 8 orang $(32 \%)$ yang dapat mencapai KKM 78, sisanya 17 orang(68\%) tidak berhasil mencapai KKM yang telah ditetapkan guru yaitu KKM 78.Artinya (68\%) siswa kelasVI B mengalami masalah/kesulitan dalam memahami Kompetensi Dasar Menyederhanakan dan Mengurutkan Pecahan .

Rendahnya kemampuan siswa pada Kompetensi Dasar Menyederhanakan dan Mengurutkan Pecahan tersebut ditandai denagn halhal berikut:

1. Kurang perhatian saat mengikuti pelajaran.

2. Siswa tidak focus saat pembelajaran berlangsung.

3. Siswa tidak aktif, dan sebagian besar hanya diam mendengarkan guru.

4. Siswa takut untuk mencoba mengeluarkan pendapat.

5. Siswa kesulitan dalam menghitung perkalian dan pembagian.

6. Siswa kurang respon ketika mengerjakan LKS

7. Siswa masih bingung melaksanakan perintah guru

8. Siswa tidak berani menjawab pertanyaan guru.

9. Dari hasil tes awal menunjukkan rata-rata 39,32 atau dibawah KKM Rendahnya kemampuan siswa pada Kompetensi Dasar Menyederhanakan dan Mengurutkan Pecahan,jika tidak segera diperbaiki akan mengakibatkan menurunnya nilai untuk pencapaian KKM.Bagi guru merupakan tantangan yang harus dihadapi dan dilaksanakan dengan penuh tanggungjawab.Bagi sekolah ada baiknya untuk meningkatkan penilaian dan kepercayaan dari masyarakat terhadap sekolah itu,bagi masyarakat akan lebih mempercayai sekolah tersebut. 
Menyadari belum optimalnya kemampuan siswa pada Kompetensi dasar "Menyederhanakan dan Mengurutkan pecahan "yang ditandai dengan rendahnya kemampuan siswa serta $68 \%$ siswa belum berhasil KKM yang telah ditetapkan,menuntut guru melakukan perbaikan pembelajaran (memandang perlu dilakukan dilaksanakan perbaikan dalam proses pembelajaran ), agar kemampuan siswa ter hadap Kompetensi Dasar "Menyederhanakan dan Mengurutkan pecahan" meningkat

Selama ini guru hanya menyajikan pembelajaran tentang Menyederhanakan dan Mengurutkan Pecahan hanya dengan menggunakan ceramah dan metode penugasan tanpa refleksi sehingga siswa tidak aktif dan tidak mendapatkan pengalaman pembelajaran yang bermakna sesuai dengan konteks kehidupan seharihari.Oleh karena itu,kemampuan dan aktifitas siswa perlu ditingkatkan.Salah satu upaya guru untuk memperbaiki /meningkatkan kemampuan dan aktifitas siswa dalam pembelajaran Kompetensi Dasar Menyederhanakan dan menyusun pecahan adalah dengan menggunakan Media pembelajaran.

Menurut Arsyad, Azhar (2002: 3),kata media berasal dari bahasa latin medius yang secara harfiah berarti 'tengah', 'perantara', atau 'pengantar'. Menurut AECTA (Association of Education and Comunication Technology, 1997),(Arsyad, Azhar 2002: 3) memberi batasan tenang media sebagai "segala bentuk dalam saluran yang digunkan untuk menyampaikan pesan atau informasi".

Kemp \& Dayton (Arsyad, Azhar,2002: 21) mengemukakan delapan manfaat media dalam kegiatan pembelajaran, yaitu:

1. penyampaian materi pelajaran dapat diseragamkan;

2. proses pembelajaran menjadi lebih menarik;

3. proses belajar siswa menjadi lebih interaktif;

4. jumlah waktu belajar-mengajar dapat dikurangi;

5. kualitas belajar siswa dapat ditingkatkan;

6. proses belajar dapat terjadi di mana saja dan kapan saja;

7. sikap positif siswa terhadap bahan pelajaran maupun terhadap proses belajar itu sendiri dapat ditingkatkan; dan

8. peran guru dapat berubah ke arah yang lebih positif dan produktif.

Arsyad, azhar (2002:75), kriteria dalam memilih media pembelajaran adalah sebagai berikut:

1. sesuai dengan tujuan yang ingin dicapai. Media dipilih berdasarkan tujuan intuksional yang telah ditetapkan.

2. Tepat untuk mendukung isi pelajaran yang sfiatnya fakta, konsep, prinsip atau generalisasi.

3. Praktis dan lama bertahan serta biaya yang terjangkau.

4. Guru terampil menggunakannya.

5. Mutu teknis., yaitu Ada beberapa kriteria untuk menilai keefektifan

Salah satu media pembelajaran yang dapat digunakan di SD adalah media papan FLanel.Media Papan Flanel adalah papan yang berlapis kain flannel,sehingga gambar atau model yang disajikan dapat dipasang,dilipat dan dilepas dengan mudah dan dapat dipakai berkali-kali.Tujuan media papan flannel adalah: 
1. Media ini digunakan untuk membedakan warna(khususnya di tingkat SD)

2. Agar bahan pelajaran lebih menarik.

Media pembelajaran ini dipilih dan digunakan sebagai solusi dalam meningkatkan kemampuan dan aktifitas siswa dalam pembelajaran matematika tentang "Menyederhanakan dan Mengurutkan Pecahan " di kelas VI B SDN.Karsamenak ,karena

1. Dapat menarik perhatian siswa

2. Gambar dapat menggugah emosi dan sikap siswa

3. Dapat mengingat dan memahami informasi

4. Dapat mengorganisasi informasi.

Berdasarkan penjelasan di atas peneliti tertarik menggunakan media papan flannel untuk meningkatkan pemahaman Mengurutkan dan Menyederhanakan dan mengurutkan pecahan di kelas VI B SDN.Karsamenak,dan menuangkan dalam laporan Penelitian Tindakan Kelas (PTK) dengan judul "Upaya Meningkatkan Kemampuan Siswa dalam Menyederhanakan dan Mengurutkan Pecahan dengan Menggunakan Media Papan Flanel di Kelas VI B SDN Karsamenak

Pemecahan masalah untuk memperbaiki /meningkatkan ,rendahnya kemampuan siswa pada Kompetensi Dasar"Menyederhanakan dan Mengurutkan Pecahan " di kelas VI B SDN.Karsamenak yang ditandai dengan rendahnya kemampuan siswa sebesar ( $68 \%$ ),siswa tersebut belum mencapai KKM yang telah ditetapkan,yang akan dilakukan peneliti adalah dengan menggunakan media papan flanel

Dengan menggunakan media papan flanel diharapkan adanya perbaikan proses pembelajaran sehingga kemampuan serta aktifitas siswa pada Kompetensi Dasar"Menyederhanakan dan Mengurutkan Pecahan di kelas VI B SDN.Karsamenak meningkat. Media pembelajaran papan flanel dalam penelitian tindakan kelas ini digunakan dengan alasan dan pertimbangan diantaranya:

1. Dapat menarik perhatian siswa

2. Gambar dapat menggugah emosi dan sikap siswa

3. Dapat mengingat dan memahami informasi

4. Dapat mengorganisasi informasi.

Media pembelajaran papan flannel dalam pembelajaran matematika Kompetensi Dasar Menyederhanakan dan Mengurutkan Pecahan di kelas VI B SDN Karsamenak dilaksanakan dengan tahapan-tahapan sebagai berikut:

1. Menyiapkan bahan untuk membuat papan flannel dan membuatnya.

2. Menyiapkan materi pembelajaran( RPP Matematika,dengan KD menyederhanakan dan mengurutkan pecahan)

3. Melaksanakan proses pembelajaran sampai evaluasi

\section{B. Metode Penelitian}

Metode yang digunakan dalam penelitian ini adalah metode penelitian tindakan kelas.Penelitian tindakan kelas ini merupakan salah satu jenis penelitian yang dapat dilakukan oleh guru atau pengajar sebagai pengelola program pendidikan.Hal ini sejalan dengan pendapat Kurt Lewin (Kusnandar 2008: 42) "Penelitian tindakan kelas adalah suatu rangkaian langkah yang terdiri atas empat tahap, yakni perencanaan, tindakan, pengamatan dan refleksi." Hal ini didukung oleh pendapat Arikunto, 
Suharsimi (2008: 8) bahwa penelitian kelas harus bersifat SMART

$\mathrm{S}=$ specific, khusus, tidak terlalu umum

$\mathrm{M}=$ managable, dapat dikelola, dan dilaksanakan

$\mathrm{A}=$ Acceptable, dapat diterima lingkungan

Achievable, dapat dicapai, dijangkau

$\mathrm{R}=$ Realistic, operasional, tidak di luar jangkauan dan

$\mathrm{T}=$ time bound, diikat oleh waktu, terencana

PTK dilakukan oleh guru dalam kelasnya sendiri melalui refleksi diri dan evaluasi yang dilakukan dengan tujuan untuk memperbaiki proses pembelajaran dalam meningkatkan hasil belajar peserta didik. Penelitian ini bersifat reflektif dengan tujuan agar kesalahankesalahan dalam pembelajaran sebelumnya tidak terulangi lagi dalam pembelajaran berikutnya. Pada Penelitian Tindakan Kelas ini, penulis memfokuskan penelitian pada upaya meningkatkan kemampuan siswa pada pelajaran matematika Kompetensi Dasar Menyederhanakan dan Mengurutkan Pecahan di kelas VI B SDN. Karsamenak dengan menggunakan papan flanel. Tujuannya adalah untuk mengetahui efektifitas atau kemanjurannya Penelitian Tindakan Kelas dalam meningkatkan kemampuan serta mengetahui seberapa besar peningkatan pencapaian pembelajaran. Melalui penggunaan media papan flanel diharapkan siswa dapat: a. Menyederhanakan pecahan desimal

b. Menyederhanakan pecahan persen

c. Menyederhanakan pecahan campuran

d. Mengurutkan pecahan yang sama penyebutnya

e. Mengurutkan pecahan yang penyebutnya berbeda

f. Mengurutkan pecahan berbagai bentuk

Penelitian Tindakan Kelas dilaksanakan di SDN.Karsamenak pada semester genap tahun pelajaran 2015/2016 ,pelajaran matematika yaitu pada tanggal 8 Pebruari tahun 2016, sesuai dengan kalender pendidikan atau kalender akademik sekolah. Pada Penelitian Tindakan Kelas ini, dilaksanakan di SDN.Karsamenak pada mata pelajaran matematika. Subjek penelitian adalah siswa kelas VI B tahun pelajaran 2015/2016, yang berjumlah 25 orang. Dalam penelitian ini,guru bertindak sekaligus sebagai peneliti. Dalam pelaksanaannya dibantu oleh teman sejawat yaitu Ibu Lina Lisnawati dan Ibu Nenu Heryani yang bertindak sebagai kolaborator atau observer yang bertugas mengamati:

1. Perencanaan Penelitian Tindakan Kelas

2. Tindakan dan Pengamatan

3. Refleksi

Sejalan dengan hal itu, bahwa desain penelitian tindakan kelas yang diambil berdasarkan adaptasi dari hopkins (Muslich, Masnur, 2009: 43) adalah sebagai berikut: 

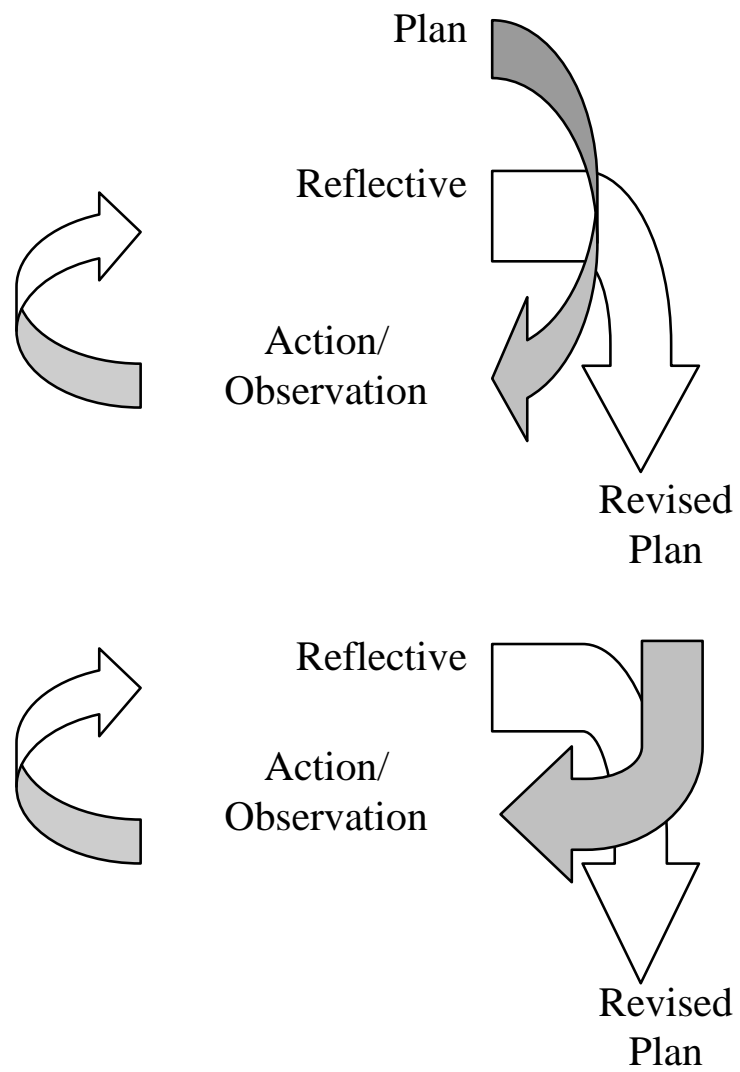

Sehingga ditemukan data tentang kemajuan pembelajaran.

Secara umum karakteristik siswa

kelas VI B SDN.Karsamenak,baik dari aspek minat,bakat,kondisi sosial ekonomi,disiplin,prestasi,aktifitas

belajar,geografis,lingkungan

belajar,menurut pengamatan penulis adalah sebagai berikut:

1. Minat belajar,pada aspek ini ratarata siswa masih kurang dalam minat belajar, seiring berkembangnya kemajuan teknologi yang berkembang begitu cepat dengan kurangnya tanggungjawab dari orang tua sehingga anak -anak lebih suka diberi alat komunikasi canggih seperti handphone dan gadget dari pada disuruh belajar atau menghapal(mengerjakan PR atau tugas-tugas sekolah), anak dibiarkan main di warnet-warnet untuk bermain game.

2. Bakat belajar pada aspek ini guru masih belum bisa mengembangkan bakat anak secara optimal,guru masih berkutat pada ruang lingkup yang sempit(hanya memenuhi pencapaian target daya serap kurikulum)

3. Kondisi sosial ekonomi,di lingkungan SDN Karsamenak secara umum orang tua siswa kebanyak bermata pencaharian sebagai buruh pada konveksi bordir(home industri), sehingga keadaan ekonominya kurang stabil, sebab ketika bos bagus bisnisnya maka ekonomi buruh tersebut bagus,tapi ketika bos nya bangkrut 
maka ekonomi buruhpun ikut bangkrut.

4. Disiplin pada aspek ini siswa masih kurang disiplin terutama disiplin dalam waktu belajar,disiplin dalam memelihara lingkungan belajar dst

5. Prestasi pada aspek ini hanya beberapa siswa yang mendapat prestasi baik di tingkat kecamatan mau di tingkat kota.

6. Aktifitas belajar siswa pada aspek ini siswa masih harus dituntun oleh guru belum ada kemauan sendiri untuk belajar,belum bisa belajar mandiri.

7. Geografis SDN. Karsamenak terletak di pinggir jalan raya oleh karena itu SDN. Karsamenak merupakan SDN yang banyak diminati oleh orang tua untuk menyekolahkan anaknya di SDN tersebut.

Lingkungan belajar, dalam aspek ini pada umumnya lingkungan belajarnya kurang sesuai karena di lingkungan SDN Karsamenak merupakan pemukiman padat penduduk sehingga untuk situasi belajar kurang memungkinkan karena gemurunya mesin komputer dan suarasuara bising membuat tidak nyaman untuk belajar

Pada Penelitian Tindakan Kelas ini,digunakan metode PTK. Langkahlangkah penelitian, Model Kemmis \& MC.Taggart memiliki empat komponen yaitu:

1. Perencanaan (Planning)

2. Tindakan (Acting)

3. Pengamatan (Observing)

4. Refleksi (Reflecting)

Pada prosesnya PTK dilaksanakan dalam 3 tahap karena tindakan dan pengamatan merupakan dua kegiatan yang tidak dapat dipisahkan karena dapat dilakukan dalam waktu bersamaan.Tiga tahap itu ialah :

1. Perencanaan (planning)

2. Tindakan dan pengamatan (action, observation)

3. Refleksi (reflection).

Dalam penelitian ini guru bertindak sekaligus sebagai peneliti.Dalam pelaksanaanya dibantu oleh teman sejawat yaitu Ibu Lina Lisnawati dan Ibu Neni Heryani yang bertindak sebagai kolaborator dan observer yang bertugas mengamati:

1. Perencanaan

2. Tindakan dan pengamatan

3. Refleksi

Sehingga ditemukan data tentang kemajuan pembelajaran tentang menyederhanakan dan mengurutkan pecahan.Digunakan model PTK sebab melalui PTK:

1. Meningkatkan mutu isi,masukan,proses dan hasil pendidikan dan pembelajaran di kelas VI B SDN.Karsamenak

2. membantu guru untuk mengatasi masalah pembelajaran.

3. Meningkatkan sikap profesional pendidik(guru)dan tenaga kependidikan

4. Menumbuh kembangkan budaya akademik di lingkungan sekolah.

5. Meningkatkan ketrampilan pendidik dalam melakukan PTK.

6. Meningkatkan kerjasama profesional diantara pendidik dan tenaga kependidikan di sekolah secara kolaboratif

Secara lebih rinci, tahapan kegiata pada siklus dijelaskan berikut ini:

\section{Siklus 1}

\section{a. Perencanaan}

Pada kegiatan ini,guru melakukan:

1) Merumuskan masalah(Siswa kurang memahami pelajaran matematika 
kompetensi dasar menyederhanakan dan mengurutkan pecahan)

2) Membuat Rencana Pelaksanaan Pembelajaran(RPP,Analisis Evaluasi)

3) Membuat Lembaran Kerja Siswa(LKS)

4) Menyiapkan media pembelajaran yang akan digunakan dalam pembelajaran.

5) Menyusun alat evaluasi pembelajaran.

\section{b. Pelaksanaan}

Pada kegiatan ini,guru melakukan:

1) Mengkondisikan siswa untuk siap belajar

2) Menyiapkan media pembelajaran yang akan digunakan(papan flanel dan gambar-gambar yang menunjang pada proses pembelajaran)

3) Menggali pemahaman siswa tentang menyederhanakan dan mengurutkan pecahan.

4) Membagikan Lembaran kerja Siswa(LKS).

5) Mengarahkan siswa dalam mengerjakan LKS tentang menyederhanakan dan mengurutkan pecahan.

6) Memberikan penguatan dan kesimpulan

\section{c. Pengamatan dan evaluasi}

1) Mengamati situasi kegiatan belajar siswa

2) Mengamati keaktifan siswa

3) Mengamati kemampuan siswa dalam mengikuti langkah-langkah dalam pengerjaan LKS.

4) Melaksanakan tes akhir.

\section{d. Refleksi}

Pada kegiatan ini guru melakukan:

1) Mengidentifikasi data yang sudah diperoleh dari hasil tes akhir.
2) Menganalisis data yang sudah diperoleh

3) Hasil analisis data digunakan sebagai acuan untuk merancang dan melaksanakan pembelajaran berikutnya.

\section{Siklus II}

\section{a. Perencanaan}

Pada kegiatan ini,guru melakukan:

1) Merumuskan masalah (Siswa kurang memahami pelajaran matematika kompetensi dasar menyederhanakan dan mengurutkan pecahan)

2) Membuat Rencana Pelaksanaan Pembelajaran (RPP, Analisis Evaluasi)

3) Membuat Lembaran Kerja Siswa (LKS)

4) Menyiapkan media pembelajaran yang akan digunakan dalam pembelajaran.

5) Menyusun alat evaluasi pembelajaran.

b. Pelaksanaan

Pada kegiatan ini,guru melakukan:

1) Mengkondisikan siswa untuk siap belajar

2) Menyiapkan media pembelajaran yang akan digunakan(papan flanel dan gambar-gambar yang menunjang pada proses pembelajaran)

3) Menggali pemahaman siswa tentang menyederhanakan dan mengurutkan pecahan.

4) Membagikan Lembaran kerja Siswa(LKS).

5) Mengarahkan siswa dalam mengerjakan LKS tentang menyederhanakan dan mengurutkan pecahan.

6) Memberikan penguatan dan kesimpulan 


\section{c. Pengamatan dan evaluasi}

1) Mengamati situasi kegiatan belajar siswa

2) Mengamati keaktifan siswa

3) Mengamati kemampuan siswa dalam mengikuti langkah-langkah dalam pengerjaan LKS.

4) Melaksanakan tes akhir.

\section{d. Refleksi}

Pada kegiatan ini guru melakukan:

1) Mengidentifikasi data yang sudah diperoleh dari hasil tes akhir.

2) Menganalisis data yang sudah diperoleh

3) Hasil analisis data digunakan sebagai acuan untuk merancang dan melaksanakan pembelajaran berikutnya

\section{Hasil Penelitian dan Pembahasan}

Gambaran Peningkatan Proses Pembelajaran Matematika Tentang Menyederhanaakan dan Mengurutkan Pecahan dengan Media Papan Flanel di Kelas VI B SDN Karsamenak.

\begin{tabular}{|c|l|c|c|c|}
\hline \multirow{2}{*}{ No } & Uraian Kegiatan/Aspek & \multicolumn{3}{|c|}{ Skor Rata-rata } \\
\cline { 2 - 5 } Kegiatan & Pra & Siklus I & Siklus II \\
\hline 1 & Apersepsi & 2 & 3 & 3,5 \\
\hline 2 & Penjelasan Materi & 2,5 & 3 & 3,3 \\
\hline 3 & Penerapan Kebiasaan Bertanya & 2 & 2,3 & 3,6 \\
\hline 4 & Teknik Pembagian Kelompok & 2 & 2,5 & 4 \\
\hline 5 & Pengelolaan Kegiatan Diskusi & 2 & 2,25 & 3,5 \\
\hline 6 & $\begin{array}{l}\text { Kemampuan Melakukan } \\
\text { Evaluasi }\end{array}$ & 2,5 & 3 & 3,75 \\
\hline 7 & $\begin{array}{l}\text { Memberikan Penghargaan } \\
\text { Individu }\end{array}$ & 2 & 4 & 4 \\
\hline 8 & $\begin{array}{l}\text { Menyimpulkan Materi } \\
\text { Pembelajaran }\end{array}$ & 2,5 & 2,5 & 3,5 \\
\hline 9 & Mengatur Waktu & 2 & 2,3 & 3,6 \\
\hline 10 & $\begin{array}{l}\text { Kemampuan Memberikan } \\
\text { Pertanyaan }\end{array}$ & 2 & 3,5 & 4 \\
\hline & Jumlah Skor & $\mathbf{2 1 , 5}$ & $\mathbf{2 7 , 8 5}$ & $\mathbf{3 3}$ \\
\hline & Rata-rata & $\mathbf{2 , 1 5}$ & $\mathbf{2 , 7 8}$ & $\mathbf{3 , 3}$ \\
\hline & Persentase & $\mathbf{5 3 , 7 5 \%}$ & $\mathbf{6 9 , 5} \%$ & $\mathbf{9 4 , 1 \%}$ \\
\hline
\end{tabular}

Gambaran peningkatan Proses pembelajaran Matematika tentang Menyederhanakan dan Mengurutkan Pecahan dengan Media Papan Flanel di Kelas VI B SDN Karsamenak ,pada para tindakan,Siklus I dan Siklus II sebagaimana disajikan pada tabel di atas secara visual dapat digambarkan dalam Grafik berikut ini: 


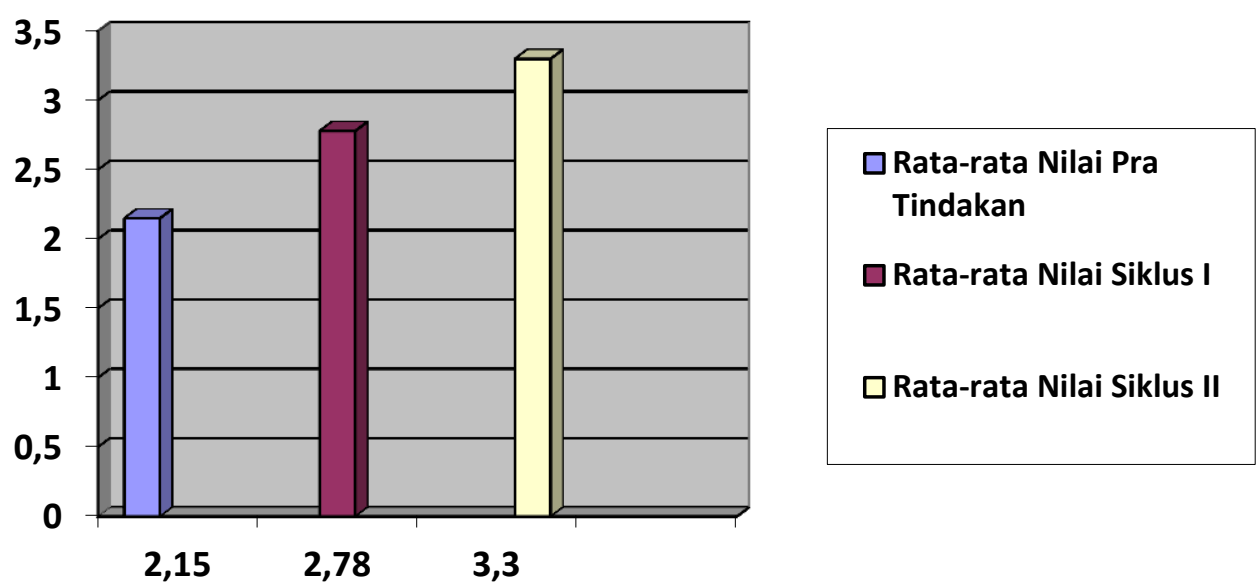

Gambaran Peningkatan Proses Pembelajaran

Berdasarkan data di atas,menunjukkan bahwa proses pembelajaran Matematika tentang Menyederhanakan dan Mengurutkan Pecahan dengan Media Papan Flanel di Kelas VI B SDN Karsamenak menunjukkan peningkatan dari siklus ke siklus .Hal ini terlihat dengan peningkatan rata-rata skor dari 2,15 atau 53,75\% pada para tindakan menjadi 2,78 atau 69,5\% pada siklus I ,Dan semakin meningkat pada siklus II yaitu 3,3 atau 94,1 \%.Hal tersebut membuktikan bahwa "Proses Pembelajaran Matematika tentang Menyederhanakan dan Mengurutka Pecahan dengan Media Papan Flanel "ratarata nilai meningkat $\mathrm{Hal}$ tersebut sejalan dengan teori/pendapat Levi \& Lentz ( 1982 ) yang menyatakan bahwa penggunaan Media Papan Flanel :

1) Dapat menarik perhatian siswa

2) Gambar dapat menggugah emosi dan sikap siswa

3) Dapat mengingat dan memahami informasi

4) Dapat mengorganisasi informasi.

Gambaran Peningkatan Aktivitas Siswa dalam Proses Pembelajaran Matematika tentang Menyederhanakan dan Mengurutkan Pecahan dengan Media Papan Flanel di Kelas VI B.SDN Karsamenak

\begin{tabular}{|c|c|c|c|c|}
\hline \multirow[b]{2}{*}{ No } & \multirow{2}{*}{$\begin{array}{c}\text { Uraian Kegiatan /Indikator } \\
\text { Keaktifan Siswa }\end{array}$} & \multicolumn{3}{|c|}{ Skor rata-rata } \\
\hline & & Pra & Siklus I & Siklus II \\
\hline 1 & Bekerjasama dalam kelompok & 2 & 4 & 5 \\
\hline 2 & Kemampuan Bertanya & 2 & 2 & 4 \\
\hline 3 & Merespon Pertanyaan Guru & 2 & 2 & 4 \\
\hline 4 & Menghargai Pendapat Siswa Lain & & & \\
\hline & & 2 & 4 & 5 \\
\hline 5 & Presentasi & 1 & 2 & 4 \\
\hline 6 & Kemampuan Menyimpulkan & 2 & 3 & 4 \\
\hline 7 & Mengerjakan Tugas & 3 & 3 & 5 \\
\hline
\end{tabular}




\begin{tabular}{|c|c|c|c|c|}
\hline \multirow[b]{2}{*}{ No } & \multirow{2}{*}{$\begin{array}{c}\text { Uraian Kegiatan /Indikator } \\
\text { Keaktifan Siswa }\end{array}$} & \multicolumn{3}{|c|}{ Skor rata-rata } \\
\hline & & Pra & Siklus I & Siklus II \\
\hline 8 & Mengemukakan Pendapat & 1 & 3 & 4 \\
\hline 9 & $\begin{array}{l}\text { Disiplin dalam Melaksanakan } \\
\text { Tugas }\end{array}$ & 2 & 3 & 4 \\
\hline 10 & $\begin{array}{l}\text { Berbicara Sopan Terhadap Guru } \\
\text { dan Teman }\end{array}$ & 2 & 3 & 5 \\
\hline & Jumlah & 19 & 29 & 44 \\
\hline & Rata-rata & 1,9 & 2,9 & 4,4 \\
\hline & Persentase & $38 \%$ & $58 \%$ & $88 \%$ \\
\hline
\end{tabular}

\section{Gambaran Peningkatan Aktivitas Siswa}
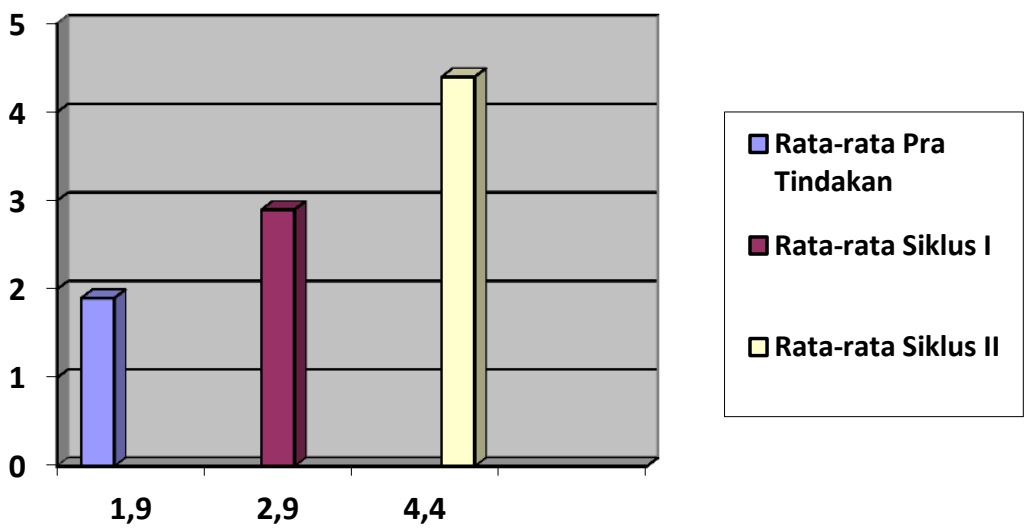

Berdasarkan data di atas menunjukkan bahwa aktivitas siswa pada pembelajaran Matematika tentang Menyederhanakan dan Mengurutkan Pecahan dengan Media Papan Flanel di Kelas VI B.SDN.Karsamenak menunjukkan peningkatan dari siklus ke siklus.Hal ini terlihat dengan peningkatan rata-rata skor 1,9 atau $38 \%$ pada Para Tindakan menjadi 2,9 atau $58 \%$ pada siklus 1,kemudian 4,4 atau $88 \%$ pada siklus II.Hal tersebut membuktikan bahwa " Proses Pembelajaran Matematika tentang Menyederhanakan dan Mengurutkan
Pecahan dengan Media Papan Flanel “dapat meningkatkan aktivitas siswa dengan teori/pendapat Levi \& Lentz ( 1982 ) yang menyatakan bahwa penggunaan Media Papan Flanel :

1) Dapat menarik perhatian siswa

2) Gambar dapat menggugah emosi dan sikap siswa

3) Dapat mengingat dan memahami informasi

4) Dapat mengorganisasi informasi. 
Gambaran Peningkatan Hasil Belajar Siswa dalam Proses Pembelajaran Matematika tentang Menyederhanakan dan Mengurutkan Pecahan dengan Media Papan Flanel di Kelas VI B.SDN Karsamenak

Gambaran Peningkatan Hasil Belajar Siswa ( Pada para -tindakan,Siklus 1 dan Siklus II)

\begin{tabular}{|c|c|c|c|c|}
\hline \multirow[b]{2}{*}{ No } & \multirow[t]{2}{*}{ Uraian Hasil Belajar Siswa } & \multicolumn{3}{|c|}{ Skor Rata-rata } \\
\hline & & Pra & Siklus I & Siklus II \\
\hline 1 & Amelia Putri & 25 & 50 & 78 \\
\hline 2 & Isty Lestari & 78 & 90 & 95 \\
\hline 3 & Oksa Mugni Dena Pratama & 78 & 78 & 85 \\
\hline 4 & Dhieni Nurfajrin & 20 & 45 & 70 \\
\hline 5 & Shalsa Juwita & 78 & 80 & 90 \\
\hline 6 & Irvan Zeni Santosa & 20 & 78 & 85 \\
\hline 7 & Ridho Arival Adrian & 78 & 80 & 78 \\
\hline 8 & Ahmad Rifqi Zulfikri & 78 & 80 & 80 \\
\hline 9 & Algi Mulyana & 25 & 40 & 80 \\
\hline 10 & Andri Andriyana & 25 & 50 & 85 \\
\hline 11 & Ananda Rahayu & 10 & 30 & 60 \\
\hline 12 & Candra Samiaji & 20 & 40 & 80 \\
\hline 13 & Emi Nurafifah & 25 & 45 & 78 \\
\hline 14 & Feri Miftah Ali & 20 & 30 & 60 \\
\hline 15 & Fadlan Muharam & 25 & 50 & 70 \\
\hline 16 & Galung Setiawan & 20 & 50 & 70 \\
\hline 17 & Farid Salim & 29 & 50 & 78 \\
\hline 18 & Faridah Awaliyyah & 15 & 40 & 80 \\
\hline 19 & Imas Maemunah & 10 & 30 & 60 \\
\hline 20 & Indriyani & 30 & 50 & 65 \\
\hline 21 & Mufti Hasnadalila & 35 & 60 & 60 \\
\hline 22 & Kintan Siti Kirani & 40 & 78 & 85 \\
\hline 23 & Resti Fauziah & 20 & 35 & 80 \\
\hline 24 & Firda Hanief & 78 & 80 & 90 \\
\hline 25 & Ridho Wahyudi & 25 & 40 & 78 \\
\hline & Jumlah & 907 & 1379 & 1920 \\
\hline & Rata-rata & 36,28 & 55,16 & $\mathbf{7 6 , 8}$ \\
\hline & Presentase & $46,51 \%$ & $70,7 \%$ & $98,46 \%$ \\
\hline
\end{tabular}


Gambaran Peningkatan Hasil Belajar Siswa

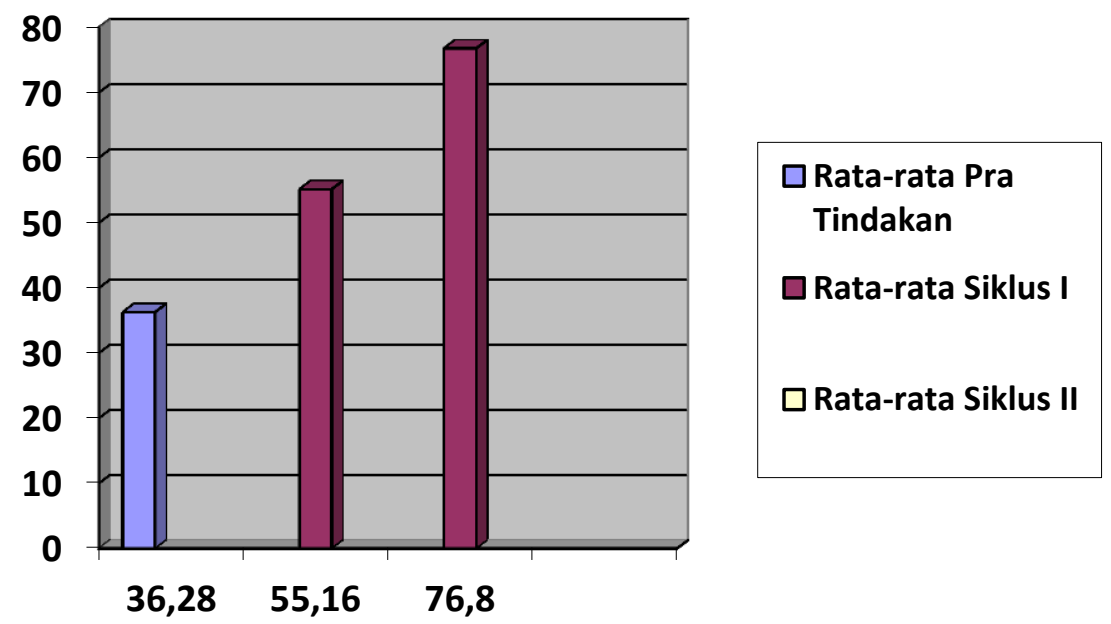

Berdasarkan data di atas, menunjukkan bahwa hasil belajar siswa pada pembelajaran Matematika tentang Menyederhanakan dan Mengurutkan Pecahan dengan Media Papan Flanel di Kelas VI B SDN Karsamenak, menunjukkan peningkatan dari siklus ke siklus.Hal ini terlihat dengan peningkatan rata-rata skor dari 36,28 atau $46,51 \%$ pada Para Tindakan menjadi 55,16 atau 70,07 \% pada Siklus 1.Kemudian semakin meningkat pada Siklus II yaitu 76,8 atau 98,46\% . Hal tersebut membuktikan bahwa " Proses Pembelajaran Matematika tentang Menyederhanakan dan Mengurutkan Pecahan dengan Media Papan Flanel "dapat meningkatkan Hasil Belajar.Hal tersebut sejalan dengan teori/pendapat Levi \& Lentz (1982) yang menyatakan bahwa penggunaan Media Papan Flanel :

1. Dapat menarik perhatian siswa

2. Gambar dapat menggugah emosi dan sikap siswa

3. Dapat mengingat dan memahami informasi

4. Dapat mengorganisasi informasi

Berdasarkan hasil penelitian tersebut dapat disimpulkan bahwa:
1. proses pembelajaran Matematika tentang Menyederhanakan dan Mengurutkan Pecahan dengan Media Papan Flanel di Kelas VI B SDN Karsamenak menunjukkan peningkatan dari siklus ke siklus .Hal ini terlihat dengan peningkatan rata-rata skor dari 2,15 atau $53,75 \%$ pada para tindakan menjadi 2,78 atau 69,5\% pada siklus I ,Dan semakin meningkat pada siklus II yaitu 3,3 atau 94,1\%.

2. Berdasarkan data di atas menunjukkan bahwa aktivitas siswa pada pembelajaran Matematika tentang Menyederhanakan dan Mengurutkan Pecahan dengan Media Papan Flanel di Kelas VI B.SDN.Karsamenak menunjukkan peningkatan dari siklus ke siklus.Hal ini terlihat dengan peningkatan rata-rata skor 1,9 atau 38 $\%$ pada Para Tindakan menjadi 2,9 atau $58 \%$ pada siklus 1,kemudian 4,4 atau $88 \%$

3. Berdasarkan data di atas,menunjukkan bahwa hasil belajar siswa pada pembelajaran Matematika tentang Menyederhanakan dan Mengurutkan Pecahan dengan Media Papan Flanel di $\begin{array}{llll}\text { Kelas } & \text { VI } & \text { B } & \text { SDN }\end{array}$ 
Karsamenak,menunjukkan peningkatan dari siklus ke siklus.Hal ini terlihat dengan peningkatan rata-rata skor dari 36,28 atau 46,51\% pada Para Tindakan menjadi 55,16 atau 70,07 \% pada Siklus 1.Kemudian semakin meningkat pada Siklus II yaitu 76,8 atau 98,46\%.

\section{Bahan Rujukan}

Arikunto, Suharsimi. (2008). Penelitian TIndakan Kelas. Jakarta: PT Bumi Aksara

Arsyad, azhar. (2002). Media Pembelajaran. Jakarta:PT Raja Grafindo Persada.
Kusnandar.(2008). Langkah Mudah Penelitian Tindakan Kelas Sebagai Pengembangan Profesi Guru.Jakarta: Rajawali Press.

Muslich, Masnur. (2009). Melaksanakan PTK (Penelitian Tindakan Kelas) Itu Mudah. Jakarta: Bumi Aksara.

Tim MKPBM. (2001). Strategi Pembelajaran Matematika Kontemporer. Bandung: JICA UPI.

Widaningsih, Dedeh. ( 2007). Telaah Kurikulum Mata Pelajaran Matematika. Diktat Kuliah.Tasikmalaya : PSPM FKIP UNSIL 